\title{
Anti-Inflammatory Activity and Cytotoxicity of the Starfish Extracts on Cancer Cells in Culture
}

\section{Jumeri Mangun Wikarta ${ }^{1,2}$ and Sang Moo Kim²*}

${ }^{1}$ Department of Agroindustrial Technology, Faculty of Agricultural Technology, Gadjah Mada University, Bulaksumur, Yogyakarta, Indonesia ${ }^{2}$ Department of Marine Food Science and Technology, Gangneung, Wonju National University, Gangneung 210-702, Republic of Korea

\begin{abstract}
Background: The starfishes were shown to containe the bioactive compounds which exhibit various biological activities including cytotoxicity, antiinflammatory, hemolytic, antibacterial, antiviral, and antifungal effects.

Objective: To determine the anti-inflammatory activity and cytotoxicity of the extracts of four different starfishes.

Materials and methods: The homogenized fresh body component of starfishes were extracted and concentrated. The EtOH extract of $A$. pectinifera with high extraction yield and total phenol was partitioned using different extraction solvents. The $\mathrm{CHCl}_{3}$ fraction was further fractionated using thin-layer chromatography, silica-gel chromatography, gel filtration, and recycling preparative HPLC, in that order.

Results: Fraction $\mathrm{SAP}_{4.2 .5}$ exhibited strong anti-inflammatory activity without cytotoxic effect up to a concentration of $25 \mu \mathrm{g} / \mathrm{mL}$, and high cytotoxicity, with $\mathrm{IC}_{50}$ values of $19.4,34.8$, and $32.7 \mu \mathrm{g} / \mathrm{mL}$ against AGS, DLD-1, and HeLa cells, respectively. These biological activities could be due to the presence of lathosterol,

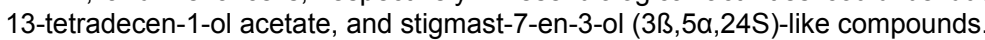

Conclusion: Starfish has a great potential as a resource for natural health products because of its strong antiinflammatory and anticancer activities.
\end{abstract}

Keywords: Anti-inflammation; Cytotoxicity; Extract; Starfish; Steroid

\section{Introduction}

Many new drugs derived from secondary metabolites have been applied in the treatment and/or prevention of various diseases. However, these drugs have various and severe adverse effects such as nausea, vomiting, edema, and diarrhea. Therefore, naturally occurring agents with high effectiveness and no side-effects are desirable chemical therapeutics.

Inflammation is a complex pathophysiological process that is mediated by a variety of signaling molecules produced by leukocytes, macrophages, mast cells, and platelets, among other cells. Macrophages play an important role in inflammatory disease through releasing factors, such as the free radical nitric oxide (NO), prostaglandin mediators, and cytokines, which are involved in the immune response [1]. Excessive production of the inflammatory mediators is associated with many diseases, such as rheumatoid arthritis, chronic hepatitis, and pulmonary fibrosis [2]. Hence, inhibiting the production of inflammatory mediators in response to inflammatory stimuli might be a useful therapeutic strategy in inflammatory diseases.

Nitric oxide (NO) is a diatomic free radical produced from $\mathrm{L}$-arginine by constitutive (cNOS) and inducible nitric oxide synthase (iNOS) in numerous mammalian cells and tissues. Nitric oxide (NO), superoxide $\left(\mathrm{O}_{2}{ }^{-}\right)$and their reaction product peroxynitrite (ONOO ) may be generated in excess during the host response against viral and antibacterial infections and may contribute to pathogenesis by promoting oxidative stress, tissue injury and even cancer [3].

Marine organisms are excellent sources of structurally diverse molecules that are potentially valuable as drugs. Many natural marine products have been designated as sources of new anti-inflammatory factors and cancer chemopreventive agents [4]. In particular, the starfishes was considered as one of the most promising sources of such agents due to the variety of species and applications of its products.

Starfish (sea star) is an invertebrate belonging to the class Asteroidea, phylum Echinodermata, of which over 1500 species are widely distributed in most of the oceans of the world. In recent years, starfish have attracted much attention due to their large scale outbreaks in coastal areas, which led to severe economic damage to the fishery and aquacultural grounds of benthic shellfishes, including mussels, oysters and scallops. Moreover, the industrial applications of the secondary metabolites of starfish have received attention worldwide. Steroidal glycosides, which are composed of a polyhydroxylated steroidal aglycone and a carbohydrate portion containing only one or two monosaccharide units, are a growing subgroup of the active glycoside compounds that have been isolated from starfishes [5]. Starfishes have also been reported to have antibacterial [6], antiviral [7], cytotoxic [8] and apoptotic [9], neuritogenic [10], antifungal [11], antityrosinase [12], anti-inflammatory [13], and anticancer $[14,15]$ activities.

The objective of this study was to determine and compare the anti-inflammatory activity and cytotoxicity against cancer cells of four starfishes, Asterina pectinifera, Asterina amurensis (the purple and yellow types) and Distolasterias nipon. Because A. pectinifera starfish is abundant and ubiquitous and has high levels of polyphenol and saponin, the anti-inflammatory and anticancer compounds of its species were purified, isolated, and identified.

\section{Materials and Methods}

\section{Animal material}

Specimens of Asterina pectinifera, purple-type Asterina amurensis,

*Corresponding author: Sang Moo Kim, Department of Marine Food Science and Technology, Gangneung, Wonju National University, Gangneung 25457, Republic of Korea, Tel: +82336402343; Fax: +82336402850; E-mail: smkim@gwnu.ac.kr

Received May 03, 2016; Accepted May 13, 2016; Published May 18, 2016

Citation: Wikarta JM, Kim SM (2016) Anti-Inflammatory Activity and Cytotoxicity of the Starfish Extracts on Cancer Cells in Culture. Med chem (Los Angeles) 6: 331338. doi:10.4172/2161-0444.1000366

Copyright: (C) 2016 Wikarta JM, et al. This is an open-access article distributed under the terms of the Creative Commons Attribution License, which permits unrestricted use, distribution, and reproduction in any medium, provided the original author and source are credited. 
yellow-type Asterina amurensis, and Distolasterias nipon were collected of the easterncoast off the Korean peninsula. The animals were brought to the laboratory in a fresh condition and were rapidly dissected and rinsed using tap water to eliminate contaminants, and were then stored at $-40^{\circ} \mathrm{C}$ until use. Immediately before use, the starfishes were thawed at $4^{\circ} \mathrm{C}$ overnight and then were sliced into small pieces using a knife. The starfish samples were placed in a stainless-steel container, frozen using liquid nitrogen, and then ground using a blender.

\section{Reagents}

Dimethyl sulfoxide (DMSO), lipopolysaccharide (LPS) from Escherichia coli 0127:B8, $\mathrm{N}_{\Psi}$-nitro-L-arginine methyl ester hydrochloride (L-NAME), Griess reagent (0.1\% napthylethylenediamine and $1 \%$ sulfanilamide in $\left.5 \% \mathrm{H}_{3} \mathrm{PO}_{4}\right)$, and 3-(4,5-dimethylthiazol-2-yl)-2,5diphenyltetrazoliumbromide (MTT) were purchased from the Sigma Chemical Co. (St. Louis, MO, USA). RPMI 1640 medium and fetal bovine serum (FBS) were purchased from Lonza (Walkersville, MD, USA). All of the other commercially available chemicals and reagents that were used were of analytical grade.

\section{Cell lines and culture}

The macrophage cell line RAW 264.7 (Korean Cell Line Bank, Seoul, Korea) was grown in plastic culture flasks in RPMI-1640 medium containing L-glutamine and supplemented with 10\% FBS, 100 $\mathrm{U} / \mathrm{mL}$ penicillin, and $100 \mu \mathrm{g} / \mathrm{mL}$ streptomycin under $5 \% \mathrm{CO}_{2}$ at $37^{\circ} \mathrm{C}$. After 3 days, the cells were removed from the culture flask by scraping and centrifuging for $3 \mathrm{~min}$ at $6,574 \times \mathrm{g}$. The medium was removed and the cells were then resuspended using fresh RPMI-1640 medium. Three cancer cell lines, a human gastric carcinoma line (AGS), a human colon cancer line (DLD-1), and a human cervical cancer line (HeLa) (ATCC, Rockville, MD, USA) were grown in RPMI-1640 medium supplemented with $10 \% \mathrm{FBS}, 100 \mathrm{U} / \mathrm{mL}$ penicillin, and $100 \mu \mathrm{g} / \mathrm{mL}$ streptomycin at $37^{\circ} \mathrm{C}$ in a humidified atmosphere of $5 \% \mathrm{CO}_{2}$. The concentration of RAW 264.7 cells was adjusted to $1 \times 10^{6}$ cells $/ \mathrm{mL}$ and that of the AGS cells, DLD-1 cells, and HeLa cells was adjusted to $1 \times 10^{5}$ cells $/ \mathrm{mL}$ using the same medium.

\section{Preparation and purification of starfish extract}

The flow chart for the purification of starfish bioactive compounds is shown in Figure 1. The homogenized fresh body component of the starfishes was extracted using $95 \% \mathrm{EtOH}$ and $\mathrm{H}_{2} \mathrm{O}$ in cold room for 6 $\mathrm{h}$, which was repeated three times. The extracts were combined and filtered. The filtrate was concentrated in vacuo at $40^{\circ} \mathrm{C}$ to the point of dryness, yielding the crude extract. Because A. pectinifera is abundant and resulted in high extraction yield as well as high amount of total phenol (Table 1), this species was chosen for further analysis. The EtOH-extracted material of $A$. pectinifera was suspended in $\mathrm{H}_{2} \mathrm{O}$. This solution was partitioned using $\mathrm{C}_{6} \mathrm{H}_{14}$ to yield a $\mathrm{C}_{6} \mathrm{H}_{14}$ fraction. Next, the aqueous layer was successively partitioned using $\mathrm{CHCl}_{3}$, EtOAc, and $\mathrm{BuOH}$, in that order. After removing each solvent by vacuum evaporation, five fractions were obtained and were hereafter referred to as the $\mathrm{C}_{6} \mathrm{H}_{14}, \mathrm{CHCl}_{3}, \mathrm{EtOAc}, \mathrm{BuOH}$, and $\mathrm{H}_{2} \mathrm{O}$ fractions.

Because the $\mathrm{CHCl}_{3}$ fraction exhibited the strongest antiinflammatory and anticancer activities (Table 2), this fraction was coarsely fractionated using silica-gel (Merck KgaA, Darmstadt, Germany) column $(3.0 \times 50.0 \mathrm{~cm})$ chromatography, using stepgradient elution with a $\mathrm{CHCl}_{3}: \mathrm{EtOH}$ solvent system of increasing polarity $(100: 0$ to $0: 100, \mathrm{v} / \mathrm{v}, 400 \mathrm{~mL})$ to yield 9 fractions $\left(\mathrm{SAP}_{1}\right.$ $\mathrm{SAP}_{9}$ ). Each $\mathrm{CHCl}_{3}: \mathrm{EtOH}$ fraction was concentrated using a vacuum evaporator (BUCHI Labortechnik AG, Postfach, Switzerland) and was finally vacuum-dried in a vacuum drying oven (Hanil, Gongju, Korea). The fraction with the highest yield, $\mathrm{SAP}_{4}$, was further fractionated

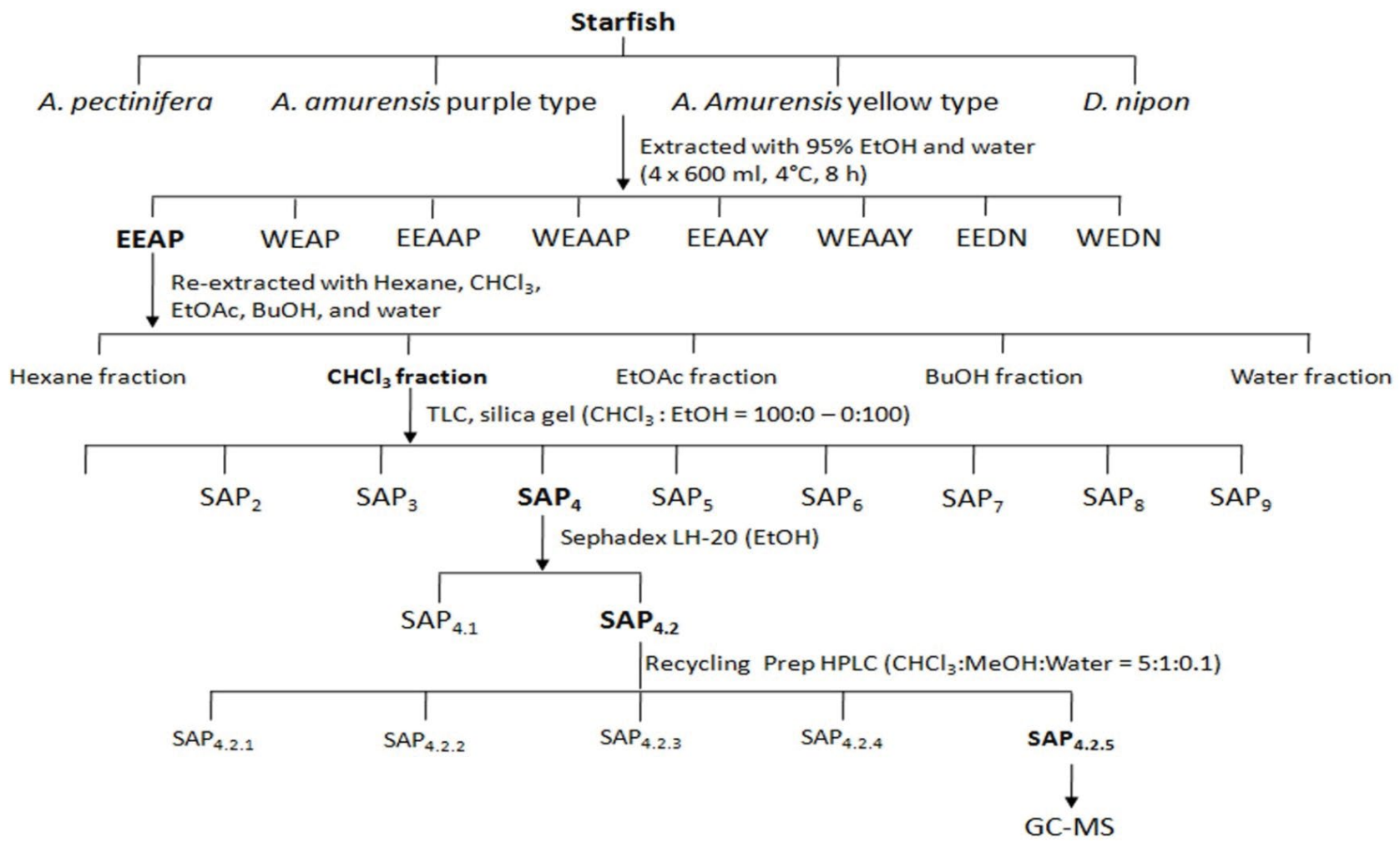

Figure 1: The flow chart for the purification of starfish bioactive compounds. 


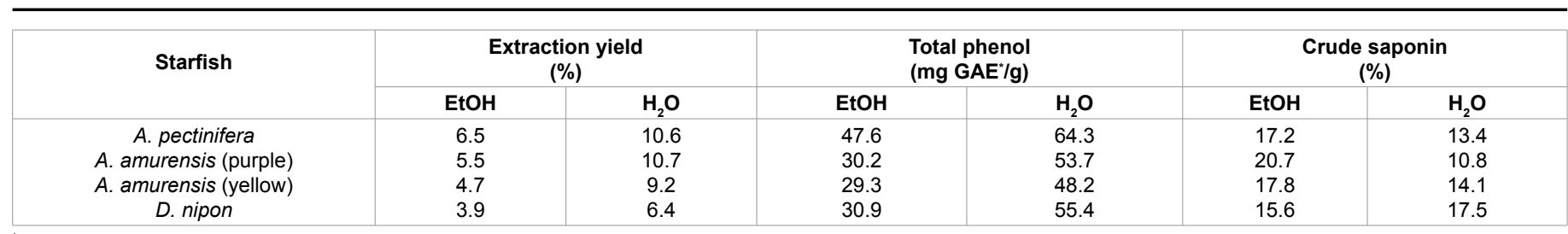

*Gallic acid equivalent

Table 1: The chemical composition of the starfish extracts.

\begin{tabular}{|c|c|c|c|c|c|}
\hline \multirow{2}{*}{ Fraction } & \multirow{2}{*}{ Yield $(\%, w / w)$} & \multirow{2}{*}{$\begin{array}{l}\text { Anti-inflammatory } \\
\quad\left(\mathrm{IC}_{50}, \mu \mathrm{g} / \mathrm{mL}\right)\end{array}$} & \multicolumn{3}{|c|}{ Anticancer $\left(\mathrm{IC}_{50}, \mu \mathrm{g} / \mathrm{mL}\right)$} \\
\hline & & & AGS & DLD & HeLa \\
\hline $\begin{array}{c}\mathrm{EtOH} \\
\mathrm{C}_{6} \mathrm{H}_{14} \\
\mathrm{CHCl}_{3} \\
\mathrm{EtOAC} \\
\mathrm{BuOH} \\
\mathrm{H}_{2} \mathrm{O} \\
\text { L-NAME }^{*} \\
5 \text { Fluorouracyl }^{* *} \\
\text { Paclitaxel }^{*}\end{array}$ & $\begin{array}{c}6.5^{\mathrm{a}} \\
33.8^{\mathrm{b}} \\
11.3^{\mathrm{b}} \\
0.1^{\mathrm{b}} \\
2.1^{\mathrm{b}} \\
31.4^{\mathrm{b}}\end{array}$ & $\begin{array}{c}292.4 \\
101.8 \\
57.3 \\
84.1 \\
115.0 \\
75.4 \\
50.0 \\
- \\
-\end{array}$ & $\begin{array}{c}269.4 \\
174.3 \\
71.8 \\
128.0 \\
129.0 \\
>400 \\
- \\
5.5 \\
3.2\end{array}$ & $\begin{array}{c}333.0 \\
150.0 \\
71.8 \\
128.0 \\
129.0 \\
>400 \\
- \\
34.5 \\
24.6\end{array}$ & $\begin{array}{c}306.9 \\
301.5 \\
77.8 \\
205.6 \\
159.4 \\
>400 \\
- \\
3.4 \\
2.2\end{array}$ \\
\hline
\end{tabular}

aPercentage of the fresh starfish $A$. pectinifera

bPercentage of the dried EtOH extract

*Anti-inflammatory positive control

"Anticancer positive control

Table 2: The anti-inflammatory and anticancer activities of starfish extracts.

using LH-20 $(3.5 \times 36 \mathrm{~cm})$ gel filtration chromatography using $\mathrm{MeOH}$ as the eluent to yield two fractions, $\mathrm{SAP}_{4.1}$ and $\mathrm{SAP}_{4.2}$. Fraction $\mathrm{SAP}_{4.2}$ was further fractionated using a recycling preparative HPLC (ModelLC-9104; Japan Analytical Industry Co. Ltd., Tokyo, Japan) equipped with a JAIGEL-GS310 column $(21.5 \times 500 \mathrm{~mm})$. Elution was performed using $\mathrm{CHCl}_{3}: \mathrm{MeOH}: \mathrm{H}_{2} \mathrm{O}(5: 1: 0.1)(\mathrm{v} / \mathrm{v} / \mathrm{v})$ with monitoring at $254 \mathrm{~nm}$ yielding five fractions $\left(\mathrm{SAP}_{4.2 .1}-\mathrm{SAP}_{4.2 .5}\right)$. The solvent in each fraction was removed using a vacuum evaporator and the samples were finally vacuum-dried in a vacuum drying oven. The fractions were then utilized in anti-inflammatory and anticancer assays.

\section{Identification of the purified compounds}

The purified compounds were identified through GC/MS analysis using a GC 7890A system equipped with a quadrupole MS 5975C detector and an HP-35 column $(30 \mathrm{~m} \times 0.25 \mathrm{~mm}$ i.d., $0.25 \mu \mathrm{m}$ film thickness) (Agilent Technologies, Waldbronn, Germany). The injection volume and port temperature were $2 \mu \mathrm{L}$ and $250^{\circ} \mathrm{C}$, respectively. The temperature of the column was started at $100^{\circ} \mathrm{C}$ for $2 \mathrm{~min}$, raised to $300^{\circ} \mathrm{C}$ at $20^{\circ} \mathrm{C} / \mathrm{min}$ and held for $6 \mathrm{~min}$. Helium was used as the carrier gas, delivered at a linear flow rate of $1 \mathrm{~mL} / \mathrm{min}$. All of the spectra were scanned within the range of 33-600 m/z. The structures of the metabolites were deduced by comparing their spectroscopic data with those reported in the library.

\section{Total phenolic and crude saponin contents}

The total phenolic content was determined using the FolinCiocalteu method [16]. The extract was appropriately diluted using the extraction solvents. One hundred $\mu \mathrm{L}$ of each diluted extract was transferred into a test tube and brought to a volume of $500 \mu \mathrm{L}$ using deionized water, after which $250 \mu \mathrm{L}$ of Folin-Ciocalteu reagent (Sigma Chemical Co.) and $1.25 \mathrm{~mL}$ of a $12.5 \%$ aqueous sodium carbonate solution were added. The mixture was vortexed and then allowed to stand for $40 \mathrm{~min}$ at room temperature. Thereafter, the absorbance of each sample at $750 \mathrm{~nm}$ was measured against that of the control $(500 \mu \mathrm{L}$ of deionized water plus $1.5 \mathrm{~mL}$ of reagent mixture) and the blank (100 $\mu \mathrm{L}$ of sample dilutent plus $1.9 \mathrm{~mL}$ of deionized water). A calibration curve was prepared using 10-50 $\mu \mathrm{g} / \mathrm{mL}$ of gallic acid (Sigma Chemical Co.) dissolved in deionized water as the standard. The total phenolic content was expressed as milligrams of gallic acid equivalent per gram of dry extract.

The crude saponin fraction was isolated according to the modified method of Ref. [17]. One gram of the starfish extract was dissolved in $125 \mathrm{~mL}$ of deionized water and the aqueous solution was transferred to a separating funnel. The solution was then treated twice using $125 \mathrm{~mL}$ of diethyl ether to remove the lipid components, and then was extracted three times using $125 \mathrm{~mL}$ of water-saturated butanol. The $\mathrm{BuOH}$ fraction was treated twice using $75 \mathrm{~mL}$ of deionized water to remove impurities. The crude saponin fraction was obtained by evaporating the $\mathrm{BuOH}$ under a reduced vacuum at $55^{\circ} \mathrm{C}$ and drying the sample at $105^{\circ} \mathrm{C}$ for $6 \mathrm{~h}$; the sample was weighed after cooling in a desiccator. The yield of crude saponin was calculated as follows:

Yield $(\%)=\left[\mathrm{W}_{\mathrm{cs}} / \mathrm{W}_{\mathrm{s}}\right] \times 100$

where $\mathrm{W}_{\mathrm{cs}}$ was the weight of the crude saponin sample and $\mathrm{W}_{\mathrm{s}}$ was the weight of the powder sample used for extraction $(1 \mathrm{~g})$.

\section{Anti-inflammatory activity}

The anti-inflammatory activity was assayed according to the modified method of Choi and Hwang [18]. Briefly, cells were seeded in 96-well tissue culture plates $\left(1 \times 10^{5}\right.$ cells $\left./ 100 \mu \mathrm{L}\right)$ and incubated at $37^{\circ} \mathrm{C}$ for $24 \mathrm{~h}$ in $5 \% \mathrm{CO}_{2}$. The extract sample was placed in phosphatebuffered saline (PBS) and was serially diluted. Cells were then stimulated with $200 \mu \mathrm{L}$ solution containing the extract, $100 \mu$ Lof LPS, and RPMI 1640 medium lacking phenol red for $24 \mathrm{~h}$. One hundred microliters of the cell-culture supernatant was mixed with $100 \mu \mathrm{L}$ of Griess reagent in the well of a 96-well plate, and the absorbance at 540 $\mathrm{nm}$ was measured $10 \mathrm{~min}$ later using a microplate spectrophotometer (EL-800; BioTek Instruments, Winooski, VT, USA). The percentage of nitric oxide inhibition was calculated based on the ability of the extract sample to inhibit nitric oxide formation by the cells compared with that of the control. The results were expressed as the percentage of inhibition of NO production compared with that of the control as follows:

$$
\% \text { inhibition }=\left[\left(\mathrm{NO}_{2}{ }^{-}\right) \mathrm{c}-\left(\mathrm{NO}_{2}{ }^{-}\right) \mathrm{s}\right] /\left(\mathrm{NO}_{2}{ }^{-}\right) \mathrm{c} \times 100
$$

where $\left(\mathrm{NO}_{2}^{-}\right) \mathrm{c}$ was the concentration of nitrite released by the cells in the absence of the extract and $\left(\mathrm{NO}_{2}^{-}\right)$s was the concentration of nitrite released by the cells in the presence of the extract. 


\section{Cytotoxicity (cell viability) assay}

To ensure that the observed inhibition of nitric oxide production of a sample was not false positive due to its cytotoxic effects, a cytotoxicity assay [19] was also performed following culture by measuring the extent of the mitochondrial-dependent reduction of MTT to formazan. To each well, $100 \mu \mathrm{L}$ of MTT $(2 \mathrm{mg} / \mathrm{mL})$ in PBS was added and the cells were incubated at $37^{\circ} \mathrm{C}$ for $4 \mathrm{~h}$ with $5 \% \mathrm{CO}_{2}$. The medium was then carefully discarded and the formed formazan salt was dissolved in $120 \mu \mathrm{L}$ of DMSO. The plates were placed at room temperature for 5 min by gently hand shaking to dissolve the formazan completely. A $100 \mu \mathrm{L}$ aliquot of the MTT formazan solution was transferred to a new 96-well tissue culture plate and then the absorbance at $540 \mathrm{~nm}$ was determined using a microplate reader (EL-800; BioTek Instruments). The absorbance of the control (untreated cells, without the extract) was taken as $100 \%$ viability. Viability was defined as the ratio (expressed as a percentage) of absorbance of the treated cells to that of the untreated cells.

\section{Cytotoxicity against cancer cells}

The cytotoxicity against cancer cells of the starfish extracts or fractions were assayed according to the modified method of Lee et al. [20]. Cells were cultured inRPMI-1640 medium supplemented with $10 \%$ heat inactivated FBS, $2 \mathrm{mM}$ glutamine, $100 \mu \mathrm{g} / \mathrm{mL}$ streptomycin and $100 \mathrm{U} / \mathrm{mL}$ penicillin at $37^{\circ} \mathrm{C}$ in $5 \% \mathrm{CO}_{2}$. For the assays, the cells were plated in 96 -well plates ( $10^{4}$ cells/well in $100 \mu \mathrm{L}$ of medium). After $4 \mathrm{~h}$, the extract or fraction, which was dissolved in $1 \times \mathrm{PBS}$, was added to each well and the plates were incubated for $72 \mathrm{~h}$. Afterward, PBS (100 $\mu \mathrm{L}$ ) containing $2 \mathrm{mg} / \mathrm{mL}$ of MTT was added to the culture medium. Three hours later, the formazan product resulting from the reduction of MTT was dissolved in DMSO, and the absorbance at $540 \mathrm{~nm}$ was measured using a microplate reader.

\section{Statistical analysis}

Each experiment was performed at least in triplicate, and the results were expressed as the mean values \pm SD. The differences among bioactivities of the fractions observed in the different assays were analyzed using an ANOVA, followed by least significance difference (LSD) test, with a p-value of $<0.05$ set as the level of significance.

\section{Results and Discussion}

\section{Extract yield, total phenolic and crude saponin contents}

The EtOH and $\mathrm{H}_{2} \mathrm{O}$ extraction yields of the four different starfishes are shown in Table 1 . The extraction yield and total phenol content of the $\mathrm{H}_{2} \mathrm{O}$ extract of all of the starfishes were higher than those of the EtOH extracts. The higher level of yield of the $\mathrm{H}_{2} \mathrm{O}$ extract might be due to starfishes containing more water-soluble substances, such as water-soluble lipids (ganglioside molecular species and a homogeneous ganglioside) and peptides [21]. Phenolics as well as non-phenolic compounds (sugars, organic acids, proteins and pigments) can be present in the extracts. The total phenolic concentration of the $\mathrm{H}_{2} \mathrm{O}$ extracts of all of the starfishes was also higher than that of the EtOH extract (Table 1). This result is contrary to the finding of Nagai et el. [22], who reported that the total phenolic content of the EtOH extract of the horsetail plant Equisetum arvense L. was higher than that of the $\mathrm{H}_{2} \mathrm{O}$ extract.

In contrast to the results regarding the content of total phenolics, the content of crude saponins of the EtOH extracts of the starfishes except for that of D. nipon was higher than that of the $\mathrm{H}_{2} \mathrm{O}$ extracts (Table 1). The secondary metabolites of starfish include a remarkable diversity of various steroids, including sterols, polyhydroxysteroids, mono- and biosides of polyhydroxysteroid, and steroid oligoglycosides called asterosaponins [23]. There are many reports of the anti-inflammatory and anticancer activities of bioactive compounds obtained from starfish, such as the anti-inflammatory activity of starfish steroids [13], and anticancer activity of polyhydroxylated steroids [24], cerebroside [8], and polysaccharides on human breast cancer [14] and colorectal adenocarcinoma cells [15]. Therefore, the starfish A. pectinifera, a carnivorous pirate invertebrate, was chosen for the extraction of antiinflammatory and anticancer compounds using different organic solvents and for their subsequent purification.

\section{Fractionation of the starfish extract}

Because A. pectinifera is an abundant raw material and its $\mathrm{EtOH}$ extract had strong anti-inflammatory and anticancer activities, this extract was consecutively fractionated using organic solvents of increasing polarity (Figure 1). Extracting fresh starfish samples using EtOH resulted in a $6.5 \%(\mathrm{w} / \mathrm{w})$ extraction yield (Table 2). It was found that partitioning the EtOH extract using $\mathrm{C}_{6} \mathrm{H}_{14}$ and $\mathrm{H}_{2} \mathrm{O}$ led to relatively high yields (33.8 and $31.4 \%$, respectively), whereas the $\mathrm{CHCl}_{3}, \mathrm{EtOAc}$, and $\mathrm{BuOH}$ fractions resulted in relatively low yields (11.3, 0.1 , and $2.1 \%$, respectively). Therefore, the compounds extracted from the starfish were distributed between polar and non-polar categories. This result is in good agreement with the findings of Higuchi et al. [10], in which ganglioside molecular species and a homogeneous ganglioside that were purified from the water-soluble lipid fractions of the chloroform/ methanol extract of $A$. pectinifera starfish were characterized.

\section{Anti-inflammatory activity}

As shown in Figure 2A, incubating RAW 264.7 cells with the starfish extract had a significant inhibitory effect on LPS-induced NO production. The $\mathrm{CHCl}_{3}$ fraction most effectively inhibited the LPSinduced NO production, with an $\mathrm{IC}_{50}$ value of $57.3 \mu \mathrm{g} / \mathrm{mL}$, whereas the EtOH extract was the least effective, with an $\mathrm{IC}_{50}$ value of 292.4 $\mu \mathrm{g} / \mathrm{mL}$ (Table 2). At $100 \mu \mathrm{g} / \mathrm{mL}$, the $\mathrm{CHCl}_{3}$ fraction inhibited $\mathrm{NO}$ production by $98.4 \%$, which was a much higher rate than those of the other fractions. These results agreed well with the results of Thao et al. [13], who reported that the $\mathrm{CH}_{2} \mathrm{Cl}_{2}$ extract of starfish Astropecten polyacanthus exerted anti-inflammatory effects on LPS-stimulated bone-marrow derived dendritic cells (BMDCs), with $\mathrm{IC}_{50}$ values of $1.27,8.82$, and $11.48 \mu \mathrm{g} / \mathrm{mL}$ for the inhibition of the production of IL12 p40, IL-6, and TNF- $\alpha$, respectively. Furthermore, 7 steroids with anti-inflammatory activity were purified from its $\mathrm{CH}_{2} \mathrm{Cl}_{2}$ extract and were identified. The decline in NO production may be attributed to the decrease in inducible NO synthase (iNOS) at the mRNA or protein level and the respective alterations of iNOS gene transcription [25]. The overexpression of pro-inflammatory cytokines, including IL-6 and TNF- $\alpha$, is associated with the progression of inflammatory diseases. Hence, blocking the production of these cytokines and their signaling pathways is very important in preventing and treating inflammatory diseases [13].

\section{Cell viability}

The cytotoxic effects of the starfish extracts and the fractions on RAW 264.7 macrophages were evaluated using the MTT assay (Figure 2B). At $100 \mu \mathrm{g} / \mathrm{mL}$, the EtOH extract of starfish and the fractions except for $\mathrm{CHCl}_{3}$ fraction, did not significantly alter cell viability over $24 \mathrm{~h}$ period. The viability rate of cells treated with the $\mathrm{EtOH}$ extract and the $\mathrm{C}_{6} \mathrm{H}_{14}$, EtOAc, $\mathrm{BuOH}$, and $\mathrm{H}_{2} \mathrm{O}$ fractions ranged from 81.3-98.2\%, whereas that of the cells treated with the $\mathrm{CHCl}_{3}$ fraction was $64.9 \%$. The cytotoxicity rate of the starfish extract and the fractions was less than 93.7\% that of L-NAME, thepositive control, at same concentration. Steroids isolated from the EtOH extract of A. pectinifera exhibited 
cytostatic activity [26]. Therefore, the lower vialbility rate of the cells treated with the $\mathrm{CHCl}_{3}$ fraction of $A$. pectinifera compared with that of the cells treated with the other fractions might be due to its content of steroid compounds.

\section{Cytotoxicity against cancer cells}

As shown in Figure 3, the EtOH extract of starfish arrested the cell cycle progression of the AGS, DLD-1, and HeLa cancer cells in a concentration-dependent manner. At $400 \mu \mathrm{g} / \mathrm{mL}$, the EtOH extract inhibited the growth of the AGS, DLD-1, and HeLa cells by 96.7, 96.5, and $92.5 \%$, respectively. The cytotoxicity of the $\mathrm{EtOH}$ extract against HeLa cells was higher than the $0.7-7.8 \%$ rate of the EtOH extract of various edible seaweeds including L. setchellii, M. integrifolia, and $N$. leutkeana against the same cells at $1,000 \mu \mathrm{g} / \mathrm{mL}$ [27], but was lower than the 78.8 and $95.5 \%$ rate of the $\mathrm{EtOH}$ extract of $C$. pilulifera against $\mathrm{HeLa}$ cells at $200 \mu \mathrm{g} / \mathrm{mL}$ after treatment for 3 and 7 days, respectively [28]. The EtOH extract was then partitioned successively using $\mathrm{C}_{6} \mathrm{H}_{14}$, $\mathrm{CHCl}_{3}, \mathrm{EtOAc}$, and $\mathrm{BuOH}$. The $\mathrm{CHCl}_{3}$ fraction inhibited the growth of cancer cells significantly more strongly than did the EtOH extract or other fractions. This fraction may alter the cell-cycle regulation, thereby reducing the proliferation rate of cancer cells. The $\mathrm{IC}_{50}$ values of the $\mathrm{CHCl}_{3}$ fraction against the AGS, DLD-1, and Hela cells were 47.2, 71.8, and $77.8 \mu \mathrm{g} / \mathrm{mL}$, respectively (Table 3 ). This result is consisted with the findings of Ref. [29], in which the $\mathrm{CHCl}_{3}$ fraction of the herb C. grandis Osbeck (Dangyuja) had the highest anticancer activity. Because the $\mathrm{CHCl}_{3}$ fraction had potent anti-inflammatory activity and cytotoxicity against cancer cells, it was conjectured that the active compounds responsible for both anti-inflammatory and anticancer activities of this fraction might be similar. Epidemiological studies have suggested that several human cancers are associated with chronically elevated levels of NO during infections [30]. Nitric oxide reacts rapidly with superoxide to form peroxynitrite, a powerful oxidant, which reacts with many biological molecules, possibly causing tissue damage. Therefore, chronic peroxynitrite exposure has been postulated as being associated with carcinogenesis due to its DNA damaging activities. Hence, DNA damage and inefficient DNA repair may initiate carcinogenesis [30]. Three polyhydroxysteroids among the 11 steroids that were isolated from three Pacific starfishes were fould to be weakly cytotoxic against $\mathrm{HeLa}$ cells, with $\mathrm{EC}_{50}$ values ranging from 53.0-174.4 $\mu \mathrm{M}$, whereas the other steroids were inactive at up to $200 \mu \mathrm{M}$ [24]. Cerebrocides purified from $A$. pectinifera starfish were also cytotoxic against two human cancer cells in a dose- and time-dependent manner up to 400 $\mu \mathrm{g} / \mathrm{mL}$ [8]. A polysaccharide of A. pectinifera starfish also inhibited the growth of human breast [14] and colorectal [15] cancer cells. Therefore, steroids, spingolipids or polysaccharides obtained from starfish might act as anticancer compounds.
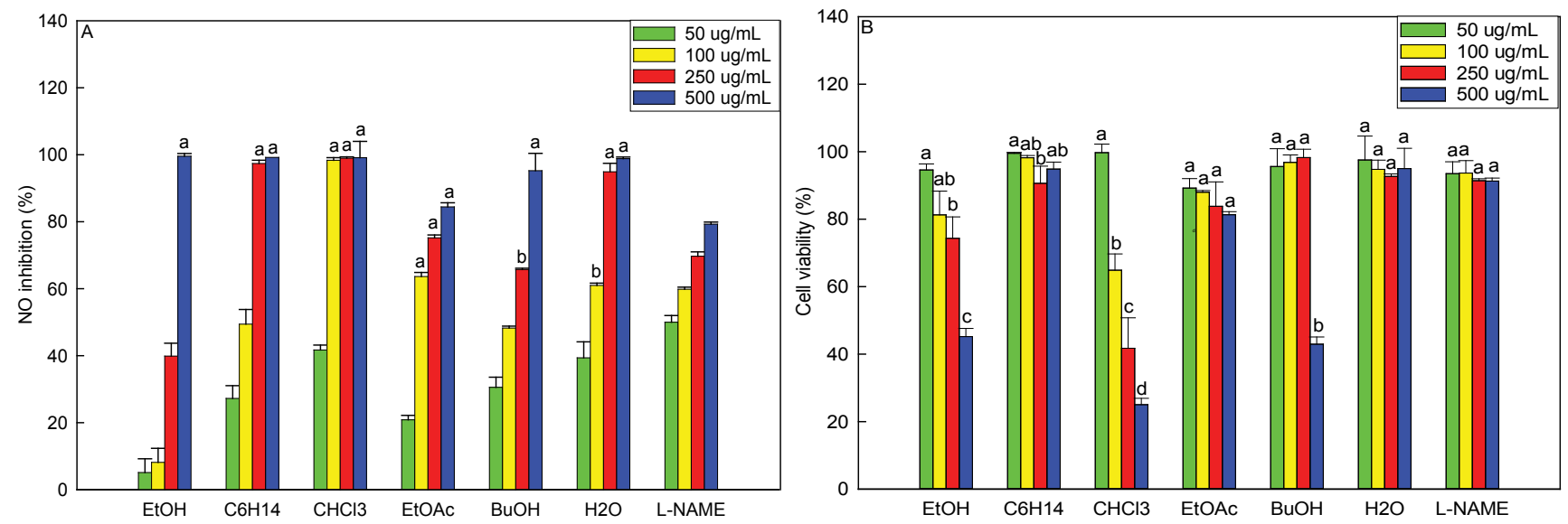

Figure 2: Anti-inflammatory activity (A) and cell viability (B) of the starfish extracts in RAW 264.7 cell at different concentrations. Values with different symbols indicate significant differences $(p<0.05)$.
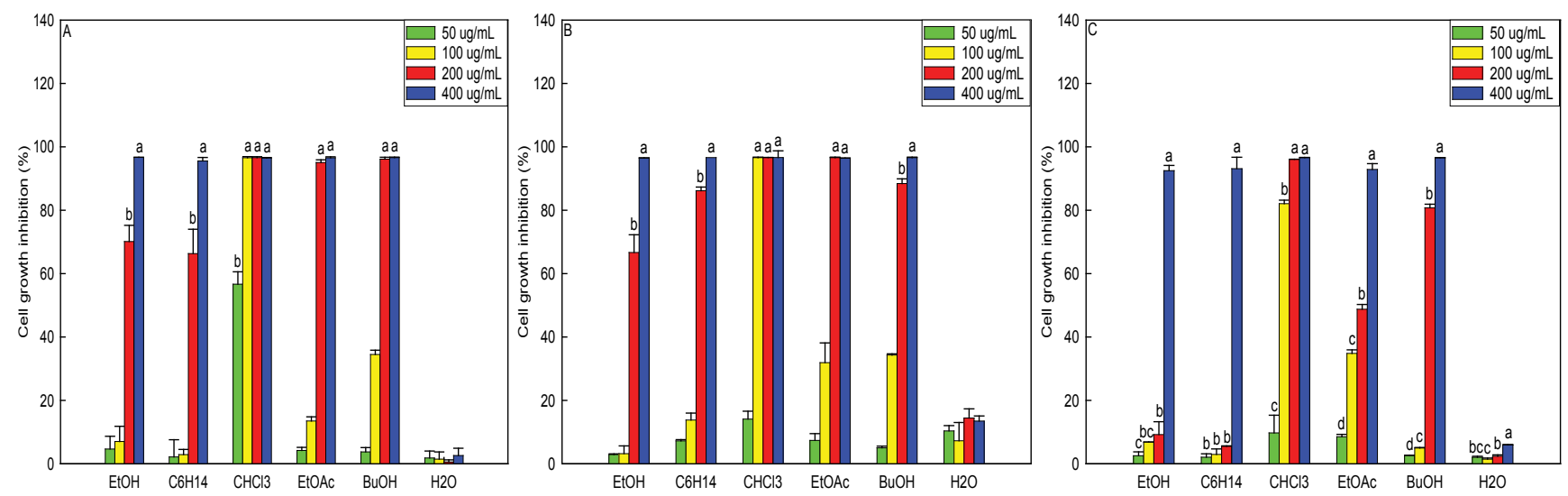

Figure 3: Cytotoxicity of the starfish ethanol extracts against AGS (A), DLD-1 (B) and HeLa (C) cancer cells at different concentrations. Values with different symbols indicate significant differences $(p<0.05)$. 


\section{Purification of anti-inflammatory and anticancer compounds}

The $\mathrm{CHCl}_{3}$ fraction was further purified using a thin layer, silicagel, and LH-20 gel filtration chromatography, and recycling preparative HPLC, in that order (Figure 1). Nine sub-fractions $\left(\mathrm{SAP}_{1}-\mathrm{SAP}_{9}\right.$ ) were obtained from the $\mathrm{CHCl}_{3}$ fraction using silica-gel chromatography. Based on the extraction yield and activity of the subfractions, subfraction $\mathrm{SAP}_{4}$ was chosen for further purification using Sephadex LH-20 gel filtration chromatography with $\mathrm{EtOH}$ as the eluent, which yielded two fractions, $\mathrm{SAP}_{4.1}$ and $\mathrm{SAP}_{4.2}$. The major fraction $\mathrm{SAP}_{4.2}$ was then applied to recycling preparative HPLC, which yielded 5 fractions $\left(\mathrm{SAP}_{42,1}-\mathrm{SAP}_{42.5}\right)$ (Figure $\left.4 \mathrm{~A}\right)$. Fraction $\mathrm{SAP}_{42.5}$ exhibited the highest anti-inflammatory activity and a high yield. Therefore, fraction SAP $_{4.2 .5}$ was analyzed using gas chromatography/mass spectrometry (GC/MS) and the obtained spectra were compared with those in the Wiley7N library, thereby revealing at least 5 components (Figure 4B). The chromatogram of this fraction resulted in clear mass spectra, even for the minor peaks, with good resolution. The chemical composition of fraction $\mathrm{SAP}_{4.2 .5}$ obtained from A. pectinifera starfish as determined using GC/MS is presented in Table 3. Peak 2 (Figure 4B), as the major component (57.9\%), had a high (96\%) amount of a compound corresponding to lathosterol $\left(\mathrm{C}_{27} \mathrm{H}_{46} \mathrm{O}, \mathrm{MW}\right.$ : 386.36). Lathosterol is a cholesterol-like molecule that is an example of a steroid. Peak 1 (6.8\%) had a high (96\%) amount of a compound corresponding to 13-tetradecen-1-ol acetate $\left(\mathrm{C}_{16} \mathrm{H}_{30} \mathrm{O}_{2}\right.$, MW: 254.22). Moreover, peak 5 (9.3\%) consisted of $94 \%$ of a compound that matched stigmast-7-en-3ol $(3 ß, 5 \alpha, 24 S)\left(\mathrm{C}_{29} \mathrm{H}_{50} \mathrm{O}, \mathrm{MW}: 414.39\right)$.

Fraction $\mathrm{SAP}_{4.2 .5}$ exhibited strong anti-inflammatory activity and cytotoxicity against cancer cellsin a dose-dependent manner (Figure 5). At $25 \mu \mathrm{g} / \mathrm{mL}$, fraction $\mathrm{SAP}_{4.2 .5}$ inhibited NO release by $92.4 \%\left(\mathrm{IC}_{50}\right.$, $14.6 \mu \mathrm{g} / \mathrm{mL}$ ) without causing cytotoxicity (cell viability >90\%) (Figure $5 \mathrm{~A}$ ), which suggested that this fraction contained NO-inhibitory compounds. However, at $50 \mu \mathrm{g} / \mathrm{mL}$, fraction $\mathrm{SAP}_{4.2 .5}$ was cytotoxic (cell viability approximately $10 \%)$. Ergost-5-en-3-ol (3ß), stigmasta-5,22Edien-3 $\beta$-ol, and stigmast-5-en-3-ol ( $3 \beta)$ purified from plant leaves exerted anti-inflammatory activity, while cholest-5-en-3-ol (3 3 ) did not [31]. Furthermore, ergosta-7,22-dien-3-ol from spiny sea-star showed stronger anti-inflammatory activity by reducing moe than $20 \%$ of NO levels than two fatty acids, cis 11 -eicosenoic and cis 11,14 eicosadienoic
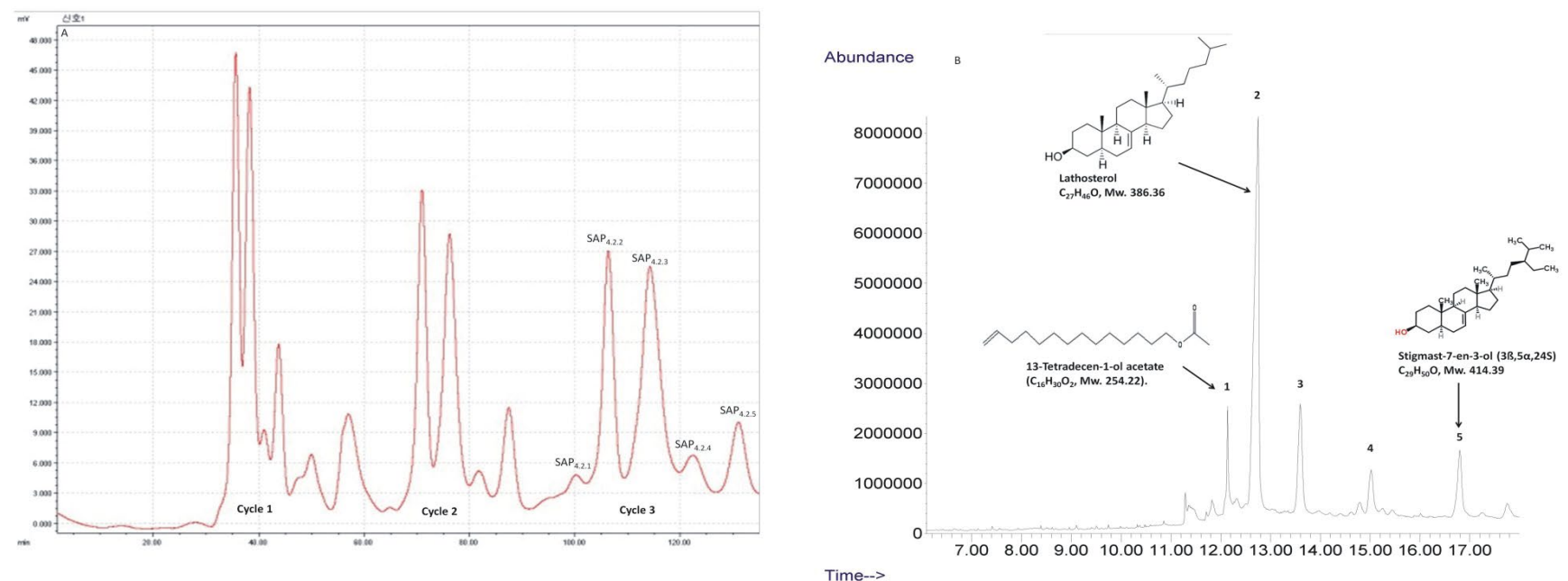

Figure 4: The purification and identification of the compounds in the starfish fractions. (A), the elution profile of $\mathrm{SAP}_{4.2}$ applied on recycling preparative HPLC; (B), total ion chromatogram of $\mathrm{SAP}_{4.2 .5}$ using GC/MS.
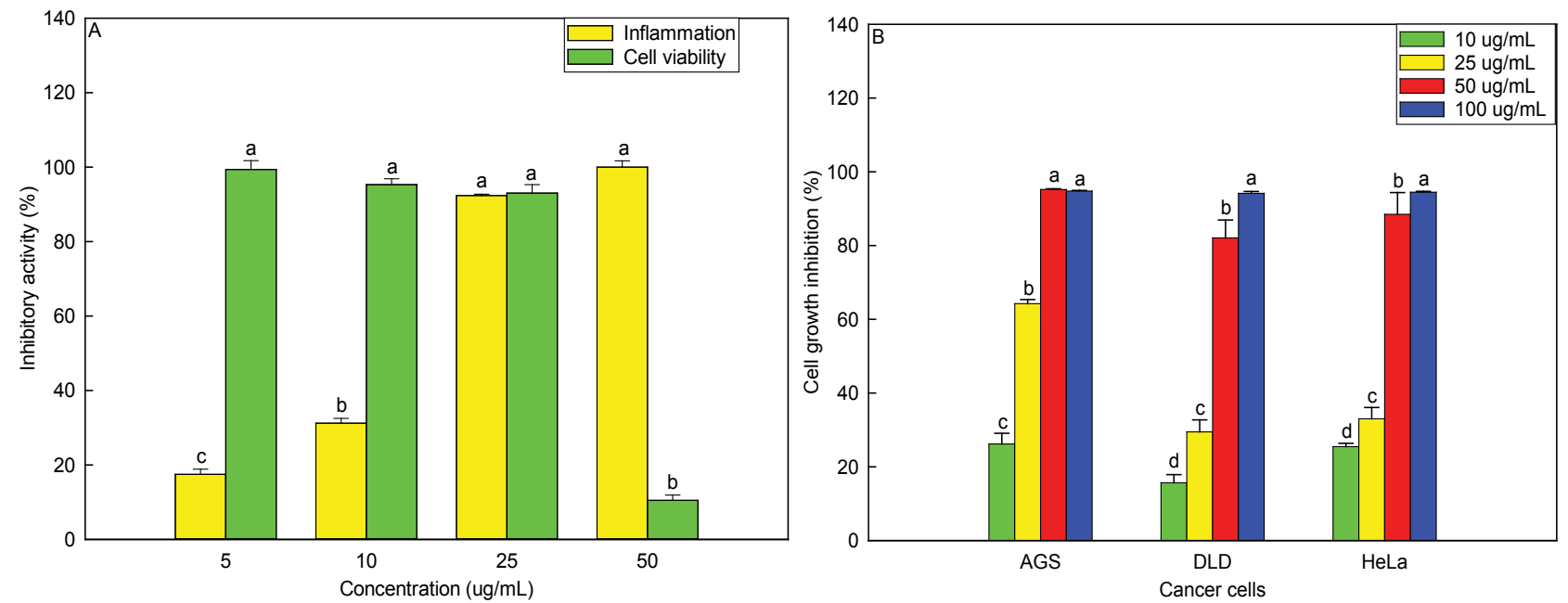

Figure 5: Anti-inflammatory activity $(\mathrm{A})$ and cytotoxicity against cancer cells $(\mathrm{B})$ of the starfish fraction $\mathrm{SAP}_{4.2 .5^{\circ}} \mathrm{Values}$ with different symbols indicate significant differences $(p<0.05)$. 


\begin{tabular}{|c|c|c|c|c|c|c|}
\hline Peak & $\mathrm{RT}$ (min) & Library & $\begin{array}{c}\text { Molecular } \\
\text { Formula }\end{array}$ & $\begin{array}{l}\text { Molecular weight } \\
\text { (Dalton) }\end{array}$ & $\begin{array}{c}\text { Match } \\
(\%)\end{array}$ & $\begin{array}{c}\text { Area } \\
(\%)\end{array}$ \\
\hline 1 & 12.138 & 13-Tetradecen-1-ol acetate & $\mathrm{C}_{16} \mathrm{H}_{30} \mathrm{O}_{2}$ & 254.22 & 96 & 6.8 \\
\hline 2 & 12.746 & Lathosterol & $\mathrm{C}_{27} \mathrm{H}_{46} \mathrm{O}$ & 386.36 & 96 & 57.9 \\
\hline 3 & 13.599 & Ergosta-7,22-dien-3-ol & $\mathrm{C}_{28} \mathrm{H}_{46} \mathrm{O}$ & 398.36 & 70 & 13.9 \\
\hline 4 & 15.022 & Androstan-11-one,3-(acetyloxy)-17-iodo-,(17a)- & $\mathrm{C}_{21} \mathrm{H}_{31} 1 \mathrm{O}_{3}$ & 458.13 & 58 & 5.6 \\
\hline 5 & 16.802 & Stigmast-7-en-3-ol, $(3 ß, 5 \alpha, 24 S)$ & $\mathrm{C}_{29} \mathrm{H}_{50} \mathrm{O}$ & 414.39 & 94 & 9.3 \\
\hline
\end{tabular}

Table 3: The chemical compositions of subfraction $\mathrm{SAP}_{4.2 .5}$ obtained from starfish extract.

acids, in RAW 264.7 cells. However, maximum acitivity was obtained when both compounds tested in combination, thus suggesting a potentially synergistic activity of both classes of metabolites [32].

Fraction $\mathrm{SAP}_{4.2 .5}$ also suppressed the proliferation of AGS, DLD1 , and HeLa cells in a dose-dependent manner (Figure 5B). At $50 \mu \mathrm{g} /$ $\mathrm{mL}$, fractionSAP ${ }_{42.5}$ significantly inhibited the growth of AGS, DLD-1, and HeLa cells by $95.2\left(\mathrm{IC}_{50}, 19.4 \mu \mathrm{g} / \mathrm{mL}\right), 82.1\left(\mathrm{IC}_{50}, 34.8 \mu \mathrm{g} / \mathrm{mL}\right)$, and $88.5 \%\left(\mathrm{IC}_{50}, 32.7 \mu \mathrm{g} / \mathrm{mL}\right)$, respectively. Hence, fraction $\mathrm{SAP}_{4.2 .5}$ inhibited the growth of AGS cancer cells more efficiently than it did that of DLD1 and HeLa cells. Many researchers have reported that starfishes contain steroids, including sterols, polyhydroxysteroids, and saponins, which appear to have anticancer activities $[33,34]$. Two polyhydroxysteroids of $A$. pectinifera starfish were also cytotoxic to the HL-60 cells, with $\mathrm{IC}_{50}$ values of 80.3 and $40.5 \mu \mathrm{M}$ [26]. A polar steroid isolated from Evasterias genus starfish were weakly cytotoxic to HeLa cancer cells [24]. Lemon essential oil containing 13-tetradecen-1-ol acetate showed inhibit the growth of HeLa cancer cells in a dose-dependent manner [35], whereas $5 a$-cholest-7-en-3 $\beta$-ol purified from A. pectinifera starfish exhibited antimutagenic activity against the mutagens MNNG and NQO [36]. The polyhydroxy steroids and saponins of A. pectinifera starfish were also cytotoxic to the human liver carcinoma HepG2 cell line [34]. A ganglioside obtained from A. pectinifera starfish was neuritogenic in the rat pheochromocytoma cell line [10]. Therefore, steroids such as lathosterol and stigmast-7-en-3-ol $(3 \beta, 5 \alpha, 24 S)$, and 13-tetradecen-1-ol acetateare considered the main anti-inflammatory and anticancercompoundsof starfish A. pectinifera.

The anticancer effect of fraction $\mathrm{SAP}_{42.5}$ might be mediated by growth inhibition of cancer cells through dysreglulated tubulin polymerization causing cell death by disrupting the normal microtubule dynamics required for cell division and vital interphase processes [37], and the inhibition of STAT3 proteins (signal transducers and activators of transcription), which are important for cancer cell survival and proliferation [38]. The mechanism underlying the anticancer activity of bioactive compounds might the activation of the host immune response, which stimulates T-cell subsets and the production of cytokines (TNF- $\alpha$ and IFN- $\gamma$ ) that participate in anticancer effects [39]. Moreover, Ref. [40] reported that a reduction in the fraction of cells in the G1 phase and the appearance of a fraction of cells with a hypodiploid DNA content was associated with delphinidin treatment of human uterine carcinoma and colon adenocarcinoma cells. Another possible anticancer mechanism of the starfish extract is the effect of the steroidal constituents of starfish on the induction of apoptosis, in which steroids in the $\mathrm{CH}_{2} \mathrm{Cl}_{2}$ fraction induced apoptosis through the downregulation of Bel-2 expression, the up-regulation of Bax expression, the cleavage of caspase- 9 and -3 , and the cleavage of poly (ADP-ribose) polymerase in HL-60 cells [13].

In the present study, the starfish extract exhibited strong antiinflammatory activity and cytotoxicity against cancer cells. Overall, these findings confirmed the utility of clinical investigations of the efficacy of starfish extracts in preventing inflammation and in cancer chemotherapy. These data can be considered an important basis for proceeding to patient studies or to the formulation of drug products.
However, further in vivo studies using animal models and human patients are necessary to develop and exploit this nascent promise.

\section{Conclusions}

The anti-inflammatory and anticancer effects of starfish extracts were evaluated to identify the beneficial effects of this species under conditions related to inflammation and cancer prevention. The starfish extracts exhibited strong anti-inflammatory and anticancer activities against human cancer cells. These biological activities of the starfish extract could be partially explained by the presence of lathosterol, stigmast-7-en-3-ol,(3ß,5a,24S)-like, and 13-tetradecen-1-ol acetatelike compounds. Based on the biofunctional activities of the starfish extract, A. pectinifera starfish could be utilized as a functional ingredient in foodor pharmaceutical products to promote human health.

\section{Acknowledgements}

This research was supported by the Korea Sea Grant Program (GangWon Sea Grant) funded by the Ministry of Oceans and Fisheries in Korea.

\section{References}

1. Hsieh SC, Fang SH, Rao YK, Tzeng YM (2008) Inhibition of pro-inflammatory mediators and tumor cell proliferation by Anisomeles indica extracts. J Ethnopharmacol 118: 65-70.

2. Heinzel FP (1990) The role of IFN-gamma in the pathology of experimental endotoxemia. J Immunol 145: 2920-2924.

3. Menichini F, Conforti F, Rigano D, FormisanoC, Piozzi F, Senatore F (2009) Phytochemical composition anti-inflammatory and antitumour activities of four Teucrium essential oils from Greece. Food Chem 115: 679-686.

4. Donia MS, Wang B, Dunbar DC, Desai PV, Patny A, et al. (2008) Mollamides $B$ and $C$, Cyclic hexapeptides from the indonesian tunicate Didemnum molle. J Nat Prod 71: 941-945.

5. Iorizzi M, Minale L, Riccio R, Debray M, Menou JL (1986) Steroidalglycosides from the starfish Halityle regularis. J Nat Prod 49: 67-78.

6. Go HJ, Jo M J, Kim GD, Park NG (2014) Biological activities of acidic extracts of the starfish Asterina pectinifera. Kor J Fish Aquat Sci 47: 122-128.

7. Wang W, Li F, Alam N, Liu Y, Hong J, et al. (2002) New saponins from the starfish Certonardoa semiregularis. J Nat Prod 65: 1649-1656.

8. Zuo H, Wang T, Qi Y, Zhao Q, Li Z (2013) Extraction, purification and cytotoxic activity of cerebrocides from Asterina pectinifera. Adv Mat Res 781: 682-686.

9. Tang HF, Cheng G, Wu J, Chen XL, Zhang SY, et al. (2009) Cytotoxic asterosaponins capable of promoting polymerization of tubulin from the starfish Culcita novaeguineae. J Nat Prod 72: 284-289.

10. Higuchi $R$, Inoue S, Inagaki K, Sakai M, Miyamoto T, et al. (2006) Biologically active glycosides from asteroidea, 42. Isolation and structure of a new biologically active ganglioside molecular species from the starfish Asterina pectinifera. Chem Pharm Bull (Tokyo) 54: 287-291.

11. Chludil HD, Seldes AM, Maier MS (2002) Antifungal steroidal glycosides from the patagonian starfish anasteriasminuta: structure-activity correlations. J Nat Prod 65: 153-157.

12. Jeong MH, Yang KM, Kim JK, Nam BH, Kim GY, et al. (2013) Inhibitory effects of Asterina pectinifera extracts on melanin biosynthesis through tyrosinase activity. Int J Mol Med 31: 205-212.

13. Thao NP, Cuong NX, Luyen BT, Quang TH, Hanh TT, et al. (2013) Antiinflammatory components of the starfish Astropecten polyacanthus. Mar Drugs 11: 2917-2926. 
Citation: Wikarta JM, Kim SM (2016) Anti-Inflammatory Activity and Cytotoxicity of the Starfish Extracts on Cancer Cells in Culture. Med chem (Los Angeles) 6: 331-338. doi:10.4172/2161-0444.1000366

14. Lee KS, Shin JS, Nam KS (2011) Cancer chemopreventive effects of starfish polysaccharide in human breast cancer cells. Biotechnol Bioproc E 16: 987991.

15. Lee KS, Shin JS, Nam KS (2012) Inhibitory effect of starfish polysaccharides on metastasis in HT-29 human colorectal adenocarcinoma. Biotechnol Bioproc E 17: 764-769.

16. Mamelona J, Pelletier E, Girard-Lalancette K, Legault J, Karboune S, et al. (2007) Quantification of phenolic contents and antioxidant capacity of Atlantic sea cucumber Cucumaria frondosa. Food Chem 104: 1040-1047.

17. Kwon JH, Bélanger JM, Paré JR (2003) Optimization of microwave-assisted extraction (MAP) for ginseng components by response surface methodology. $J$ Agric Food Chem 51: 1807-1810.

18. Choi EM, Hwang JK (2005) Screening of Indonesian medicinal plants for inhibitor activity on nitric oxide production of RAW 2647 cells and antioxidant activity. Fitoterapia 76: 194-203.

19. Abas F, Lajis NH, Israf DA, Khozirah S, Kalsom YU (2006) Antioxidant and nitric oxide inhibition activities of selected Malay traditional vegetables. Food Chem 95: 566-573

20. Lee JY, Hwang WI, Lim ST (2004) Antioxidant and anticancer activities of organic extracts from Platycodon grandiflorum A. De Candolle roots. J Ethnopharmacol 93: 409-415.

21. Lou H, Gao Y, Zhai M, Qi Y, Chen L, et al. (2008) A novel peptide from alpha5 helix of Asterina pectinifera cyclin B conjugated to HIV-Tat(49-57) with cytotoxic and apoptotic effects against human cancer cells. Bioorg Med Chem Lett 18: 4633-4637.

22. Nagai T, Myoda T, Nagashima T (2005) Antioxidative activities of extract and ethanol extract from field horsetail (tsukushi) Equisetum arvense L. Food Chem 91: $389-394$

23. Kicha AA, Ivanchina NV, Gorshkova IA, Ponomarenko LP, Likhatskaya GN, et al. (2001) The distribution of free sterol polyhydroxysteroid and steroid glycosides in various body components of the starfish Patiria (= Asterina) pectinifera. Comp Biochem Physiol B Biochem Mol Biol 128: 43-52.

24. Levina EV, Aminin DL, Koval'chuk SN, Kozhemiako VB, DyshlovoÄ SA, et al. (2010) Polar steroids from Solaster endeca starfish and the physiological activity of polar steroids from three starfish species. Bioorg Khim 36: 251-258.

25. Wu LC, Fan NC, Lin MH, Chu IR, Huang SJ, et al. (2008) Anti-inflammatory effect of spilanthol from Spilanthes acmella on murine macrophage by downregulating LPS-induced inflammatory mediators. J Agric Food Chem 56: 2341 2349.

26. Li Z, Chen G, Lu X, Wang H, Feng B, et al. (2013) Three new steroid glycosides from the starfish Asterina pectinifera. Nat Prod Res 27: 1816-1822.
27. Yuan YV, Walsh NA (2006) Antioxidant and antiproliferative activities of extracts from a variety of edible seaweeds. Food Chem Toxicol 44: 1144-1150.

28. Kwon H, Bae S, Kim K, Han C, Cho S, et al. (2007) Induction of apoptosis in HeLa cells by ethanolic extract of Corallina pilulifera. Food Chem 104: 196-201.

29. Kim H, Moon JY, Mosaddik A, Cho SK (2010) Induction of apoptosis in human cervical carcinoma HeLa cells by polymethoxylated flavone-rich Citrus grandis Osbeck (Dangyuja) leaf extract. Food Chem Toxicol 48: 2435-2442.

30. Liu RH, Hotchkiss JH (1995) Potential genotoxicity of chronically elevated nitric oxide: a review. Mutat Res 339: 73-89.

31. Mujeeb F, Bajpai P, Pathak N (2014) Phytochemical evaluation, antimicrobia activity, and determination of bioactive components from leaves of Aegle marmelos. Biomed Res Int 2014: 497606.

32. Pereira DM, Correia-Da-Silva G, Valentao P, Teixeira N, Andrade PB (2014) Anti-Inflammatory Effect of Unsaturated Fatty Acids and Ergosta-7,22-dien-3-ol from Marthasterias glacialis: Prevention of CHOP-Mediated ER-Stress and NFKB Activation. PLOS ONE 9: e88341.

33. Alla AK, Natalia VI, Trinh TTH, Anatoly IK, Pavel SD, et al. (2010) Two new asterosaponins, archasterosides $A$ and $B$, from the Vietnamese starfish Archaster typicus and their anticancer properties. Bioorg Med Chem 20: 38263830 .

34. Peng Y, Zheng J, Huang R, Wang Y, Xu T, et al. (2010) Polyhydroxy steroids and saponins from China Sea starfish Asterina pectinifera and their biological activities. Chem Pharm Bull (Tokyo) 58: 856-858.

35. Huang CY, Pu H, Zhang ZY, Song J (2010) Evaluation of antioxidant and antitumour activities of lemon essential oil. J Med Plant Res 4: 1910-1915.

36. Han YH, Ham JH, Lee NJ, Park CH, Shin YH, et al. (2000) Antimutagenic activity of 5alpha-cholest-7-en-3beta-ol, a new component from the starfish asterina pectinifera. Biol Pharm Bull 23: 1247-1249.

37. Cragg GM, Newman DJ (2005) Plants as a source of anti-cancer agents. J Ethnopharmacol 100: 72-79.

38. Pathak AK, Bhutani M, Nair AS, Ahn KS, Chakraborty A, et al. (2007) Ursolic acid inhibits STAT3 activation pathway leading to suppression of proliferation and chemosensitization of human multiple myeloma cells. Mol Cancer Res 5 : 943-955.

39. Chen R, Meng F, Liu Z, Chen R, Zhang M (2010) Antitumor activities of different fractions of polysaccharide purified from Ornithogalum caudatum Ait. Carbohyd Polym 80: 845-851.

40. Yi W, Fischer J, Akoh CC (2005) Study of anticancer activities of muscadine grape phenolics in vitro. J Agric Food Chem 53: 8804-8812. 